\title{
Fish assemblage structure in tributaries of the Meia Ponte River, Goiás, Brazil
}

\author{
Afonso P. Fialho*, Leandro G. Oliveira**, Francisco L. Tejerina-Garro* \\ and Luiz C. Gomes***
}

This study was conducted in the Meia Ponte River basin, which is located in the Cerrado biome. The objective was to describe the structure of fish assemblages and to evaluate the results with the regard to the position of the tributaries (sampling stations) along the basin. This basin drains 35 municipalities of Goiás State. Springs of the Meia Ponte are located in the district of Itauçu (GO), in the Serra dos Brandões. Two sampling were conducted, one in the rainy season (March/2001) and another in the dry season (August/2001). Thirty sampling sites in tributaries and one in the channel of the Meia Ponte River, in its upper course, were selected to capture fish with dipnets $(3 \mathrm{~mm}$ mesh) during one hour, along 100-m stretch. Sampling periods (season; rainy and dry) and the categorization according to the distance of the sampling station from the mouth of the Meia Ponte River (position; upper, intermediate and lower) were used to evaluate differences in fish assemblage structure, summarized by a detrended correspondence analysis (DCA), applied on the abundance data matrix, squared root transformed, to eliminate the effect of abundant species. The first two axes were retained for interpretation (eigenvalues $=0.35$ and 0.24 , for axis 1 and 2 , respectively). The two-way ANOVA (factors seasons and positions) identified significant differences $(\mathrm{p}<0.05)$ in score averages for axis 1 and 2, for both factors. These results suggest significant differences in fish assemblage structure in the Meia Ponte River basin for the seasons (rainy and dry) and positions (upper, intermediate and lower) studied, in spite of the short spatial scale. These findings demonstrate a great ichthyofauna heterogeneity in the uppermost part of the Paraná River.

Este estudo foi realizado na bacia do rio Meia Ponte, a qual está localizada no bioma cerrado. O objetivo foi descrever a estrutura da assembléia de peixes, relacionando os resultados com a distribuição longitudinal dos afluentes ao longo da bacia do rio Meia Ponte. Essa bacia hidrográfica drena 35 municípios Goianos, sendo suas nascentes localizadas no município de Itauçú (GO), na Serra dos Brandões. Foram realizadas duas coletas, uma no mês de março/2001 (chuva) e a outra em agosto/ 2001 (seca). Trinta afluentes e um ponto na calha do rio Meio Ponte, na sua porção mais superior, foram selecionados para a captura dos peixes, com uso de peneiras $(3 \mathrm{~mm}$ ) durante uma hora, em uma secção de $100 \mathrm{~m}$. O período de amostragem (fase; seca e chuva) e a categorização em função da distância do ponto de amostragem até sua desembocadura (posição; alto, médio e foz) foram utilizados como fatores. O protocolo utilizado para avaliar a estrutura da comunidade considerou a análise de correspondência com remoção do efeito de arco (DCA), que sumarizou a matriz de abundância, transformada em raiz quadrada, para remover o efeito de espécies muito abundantes. Os dois primeiros eixos foram retidos para interpretação, com autovalores de 0,35 e 0,24 , para o eixo 1 e 2 , respectivamente. AANOVA bifatorial (fase e posição) identificou diferenças significativas ( $p<$ $0,05)$ na média dos escores dos eixos 1 e 2 , para os dois fatores. Estes resultados demonstram que a estrutura da comunidade de peixes foi diferente entre as estações do ano (seca e chuva) e posição do ponto de amostragem ao longo do rio (alta, intermediária e baixa), apesar da escala espacial pequena. Então, foi verificada uma acentuada heterogeneidade na ictiofauna das áreas mais superiores do rio Paraná.

Key words: Upper rio Paraná, Cerrado, Streams.

\footnotetext{
*Centro de Biologia Aquática, Universidade Católica de Goiás, Campus II, Av. Engler, J. Mariliza, Cx. Postal 86, CEP 74605-010 Goiânia, GO,Brazil. afonso@ucg.br; garro@ucg.br

**Laboratório de Limnologia, Universidade Federal de Goiás, Dpto. de Biologia, Instituto de Ciências Biológicas, Campus II Itatiaia, Goiânia, GO, Brazil. lego@icb.ufg.br

***Núcleo de Pesquisas em Limnologia, Ictiologia e Aqüicultura, Universidade Estadual de Maringá, DBI/Nupélia. Av. Colombo, 5790, Maringá, PR, Brazil.lcgomes@nupelia.uem.br
} 


\section{Introduction}

The identification of environmental gradients structuring fish assemblages is one of the main challenges of stream ecologists (Gilliam et al., 1993). Hughes \& Gammon (1987) stated that physiographies of the basins are the environmental parameters traditionally used to explain ichthyological regions, and these are large areas where similar fish assemblages are found. In addition, Grenouillet et al. (2004) report that species richness of streams, within a hydrographic basin, may be influenced by local habitat conditions (local factors) and stream order along a watershed. The latter is dependent on stream geographical position within a basin. Other studies associate the structure of fish assemblages with the historical formation of a hydrographic basin (Williams et al., 2003), different habitats and/or microhabitats (i.e. MarshMatthews \& Matthews, 2000) and the increase in water volume and shelter availability as well (Araújo-Lima et al., 1998; Jackson et al., 2001).

Studies on the variability of fish assemblages in streams located in the same river basin are fundamental to understanding the functioning of these systems. The most adequate framework to achieve this is the fish-habitat interaction. This also allows the evaluation of the relationship between aquatic and terrestrial habitats, because fish use terrestrial alimen- tary resources such as insects and fruits, among others (Harris, 1995), which are important for planning the conservation of biodiversity (Matthews, 1998; Gorshkov et al., 2004). For neotropical water courses, some authors determined the structure of fish assemblages, and used environmental variables such as stream order and distance from the source (Bistoni \& Hued, 2002), topography, stream order, and water flow velocity and volume (Uieda \& Barretto, 1999) to explain them. In addition, other studies consider abiotic (physical characteristics, geology and hydrology) and biotic (predation) factors, human occupation, agriculture and urbanization. All these induce alteration in habitats and, consequently, in the biota along a water course (Balon, 1993; Penczak et al.,1994; Moyle, 1995; Wiens, 2002; Solé et al., 2003).

The river basin studied has been altered by anthropogenic impacts, such as agriculture, ranching, industrialization and urbanization. These impacts result in the removal of vegetation, sand accumulation in river beds, damming and introduction of exotic species. Thus, the purpose of this study was to determine if geographic position (position of the stream within the basin) and season (rainy and dry) are good predictors of fish assemblage structure in streams of the uppermost part of the Paraná River basin under pressure due to man-made impacts.

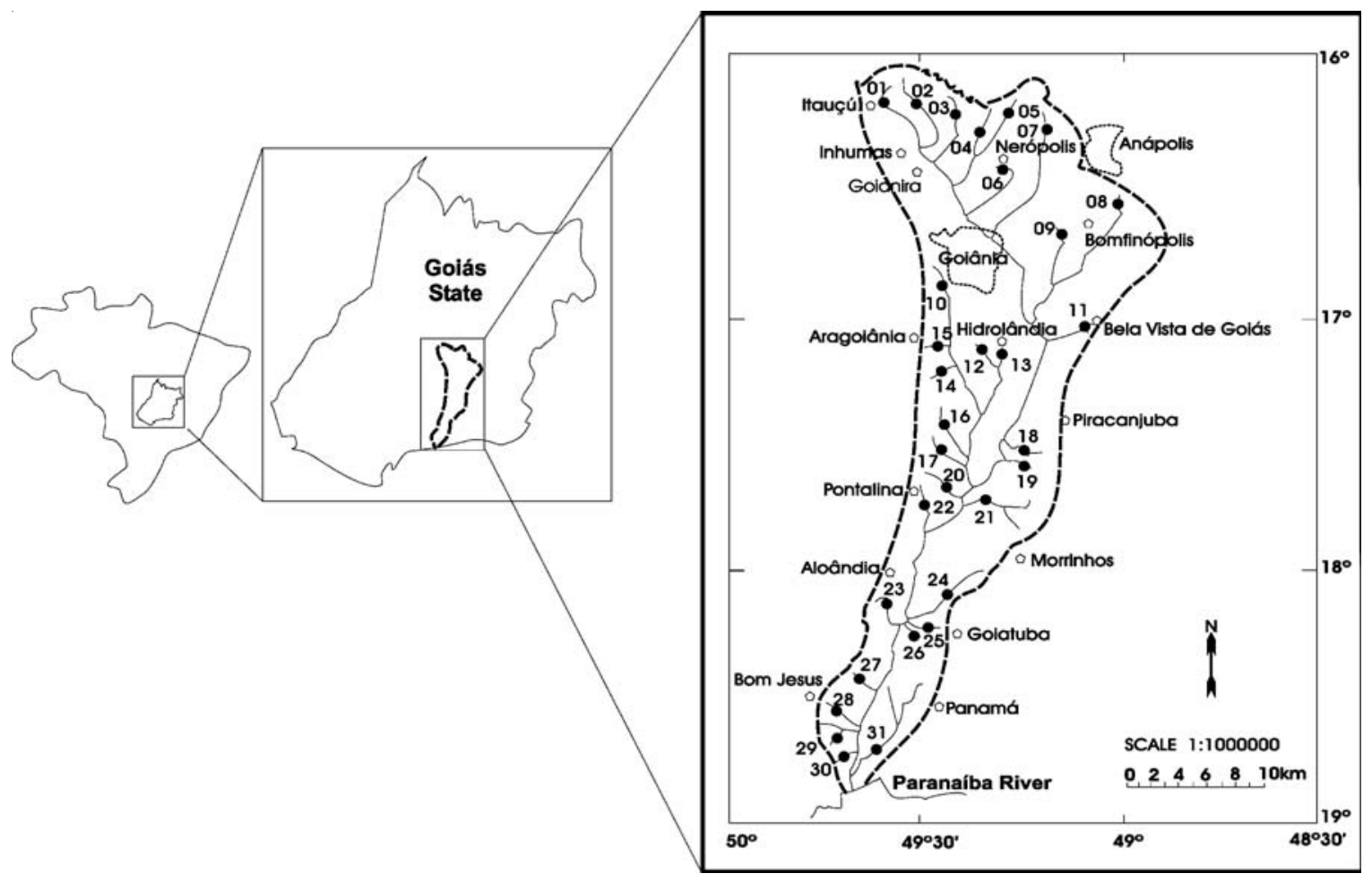

Fig. 1. Location of the sampling stations (black circles) in the Meia Ponte River basin in the State of Goiás, Brazil, and the cities in the region (open circles). Numbers are the sampling stations: $01=$ Meia Ponte River; $02=$ Inhumas River; $03=$ Capoeirão stream; $04=$ Gonçalves stream; $05=$ Cachoeirão stream; 06 = Capivara stream; $07=$ João Leite stream; $08=$ Caldas stream; $09=$ Sozinha stream; $10=$ Dourado River; $11=$ Aborrecido stream; $12=$ Bonito stream; $13=$ Meio stream; $14=$ Bom Sucesso stream; $15=$ Cachoeira stream; $16=$ Santa Rita stream; 17 = Paraíso stream; $18=$ São Pedro stream; $19=$ Bocainas stream; $20=$ Água Limpa stream; $21=$ Formiga stream; 22 = Boa Vista do Rancho stream; 23 = São Domingos stream; 24 = Fundo stream; 25 = Lageado stream; $26=$ Divisa stream; $27=$ Neves stream; $28=$ Boa Vista stream; $29=$ Bebedouro stream; $30=$ Sapê stream; 31 = Boa Vereda stream. 


\section{Material and Methods}

\section{Study area}

Meia Ponte River basin is located between the parallels

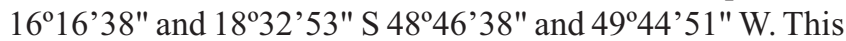
river belongs to the upper Paranaíba River basin, which forms, together with the Grande River, the Paraná River. Springs of the Meia Ponte River are located in the Serra dos Brandões, municipality of Itauçú (Goiás). The Meia Ponte is $480 \mathrm{~km}$ long and its mouth in the Paranaíba is in the Municipality of Cachoeira Dourada. It drains an area of $12,350 \mathrm{~km}^{2}$, where there are 35 municipalities of the Goiás State (Goiás, 2000; Fialho \& Tejerina-Garro, 2004) (Fig. 1).

\section{Sampling}

During the period studied, 31 stations (30 distributed along tributaries and one in the main channel of the Meia Ponte) were sampled. Streams and stations were chosen considering access facilities. Positions of the stations were determined using global positioning system (GPS; Garmin II) and maps (scale 1: 100,000) produced by the Instituto Brasileiro de Geografia e Estatística (IBGE). Afterward, the distance of every station from the Meia Ponte mouth was determined using a Meilograph pen. The altitude of each station was also obtained. The data (distance from the mouth and altitude) were evaluated graphically, and used as a criterion to categorize stations in upper, intermediate and lower courses (herein named positions).

For every station, a 100-m long stretch was sampled during the rainy (March/2001) and dry (August/2001) seasons. Fish were captured with dipnets ( $3 \mathrm{~mm}$ mesh), handled by five persons who walked twice in the stretch, for about an hour. All sampled fish were fixed in 10\% formalin and sent to the laboratories of the Centro de Biologia Aquática (CBA) of the Universidade Católica de Goiás. Six individuals of each species were added to the CBA fish collection and similar numbers were sent to the Núcleo de Pesquisas em Limnologia, Ictiologia e Aquicultura of Universidade Estadual de Maringá, to confirm identification.

\section{Data analysis}

To achieve the objectives of this study, a species abundance matrix (sampling stations and seasons in rows and species in columns) was summarized by a multivariate technique (ordination), detrended correspondence analysis (DCA) (Gauch Jr., 1982; Jongman et al., 1987), using the software PcOrd (McCune \& Mefford, 1997). DCA is an indirect eigenvector ordination technique based upon reciprocal averaging that corrects for the "arch effect" observed in correspondence analysis (Feyrer \& Healey, 2003). Thus, patterns in the structure of fish assemblages of the Meia Ponte River basin were summarized in the axes retained for interpretation (axis with eigenvalues $>0.20$, as recommended by Matthews, 1998). To eliminate the effects of highly numerous species on the ordination, analysis was conducted using transformed (square roots) abundances.
As DCA only gives two diagrams representing the stations and species, we generated the scores of the samplings controlling seasons (rainy and dry) and positions (upper, intermediate and lower). Seasons and positions were then used as factors (ANOVA terminology), to determine differences in fish assemblages. Consequently, we assumed that differences in mean scores according to the factors considered (and their interaction) represent distinct fish assemblage structures, now represented in the scores of the axes retained for interpretation. To determine the species that most influenced ordination, the option correlation with main matrix available in PcOrd was run. This option calculates Pearson's correlation for each species, which represents their correlation with a given axis.

As several axes can potentially be retained for interpretation, several two-way ANOVAs could be conducted, running into the problem related to multiple tests that increase the probability of Type I error. To overcome this problem, we used the protected ANOVA protocol (Scheiner \& Gurevitch, 1993; Johnson, 1998). In this protocol, a MANOVA is first applied (for the two factors and axes retained for interpretation), and only if it was significant, two-ways ANOVA for each axis would be conducted separately.

Species richness, Shannon-Wiever diversity index and equitability were calculated according to position and season using the software Biodiversity Professional 2.0. Differences among means of these variables were also tested by the protected ANOVA protocol.

Assumptions of ANOVA were examined by the Shapiro Wilk (normality) and Levene (homogeneity of variances) tests. The parametric tests (MANOVA and ANOVAs) were conducted using the software Statistica 6.0.

\section{Results}

Sampling stations were categorized, according to distance from the mouth of the Meia Ponte River and altitude, as in upper (stations p1 to p9), intermediate (stations p10 to p20 and p22 and p23) and lower (stations p21 and p24 to p31) (Fig. 2). For all stations, a total of 3595 individuals belonging to five orders, 19 families and 59 species were caught (Table 1). Eight species showed high numeric abundances. They are Poecilia reticulata (22.14\%), Astyanax eigenmanniorum (10.45\%), Bryconamericus sp. 1 (7.92\%), Bryconamericus stramineus (7.48\%), Astyanax fasciatus (6.75\%), Hypostomus ancistroides (5.95\%), Hypostomus sp. (5.06\%) and Corydoras sp. $(4.42 \%)$ (Table 1$)$.

Two axes of detrended correspondence analysis were retained for interpretation (eigenvalues for axis $1=0.36$ and for axis $2=0.25$; total variance explained $=26.4 \%$ ). In the ordination, the separation of the seasons is clear (the majority of the black circles - rainy season, is located on the right side of the ordination; Fig. 3). However, there is no clear pattern related to the position of the sampling stations along the river basin (upper, intermediate and lower). To solve this problem, we generated scores controlling for seasons and positions, and 


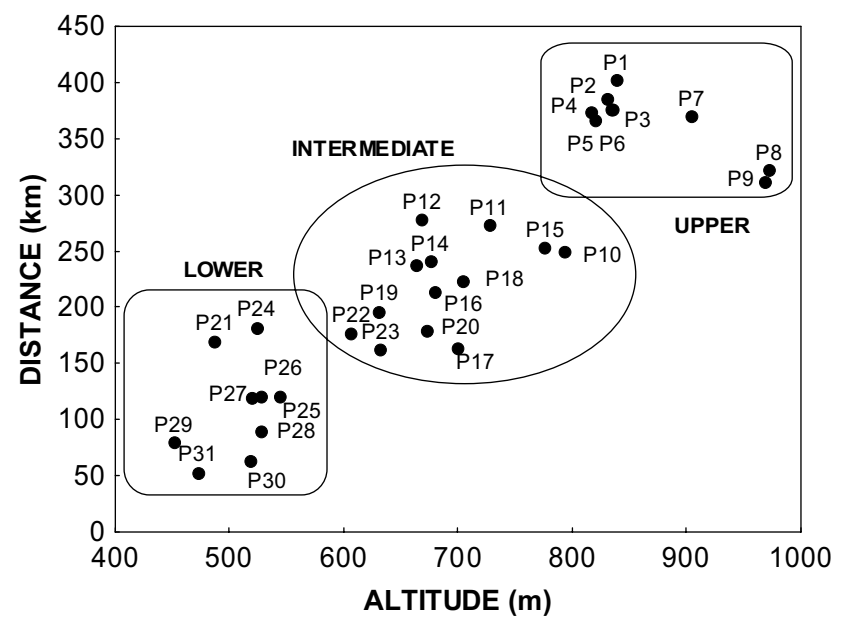

Fig. 2. Position of the sampling stations (upper, intermediate and lower) according to altitude and distance from the mouth of the Meia Ponte River. they were used as variables in further tests. Considering the protected ANOVA protocol, the two-way MANOVA was significant (all factors except the interaction; Table 2), indicating the appropriateness of applying two-way ANOVAs for each axis. The two-way ANOVAs identified significant differences in seasons and positions for both axes except the interaction (Table 2; Figs. 4 a-b). Therefore, it is possible to conclude that the fish assemblages varied between rainy and dry seasons and among positions (greatest difference between upper and lower; Tukey's test; $p=0.005$ for axis $1 ; p=0.044$ for axis 2). Assumptions of ANOVA were met (Shapiro - Wilk > 0.05 ; Levene $>0.05$ ).

The species that most influenced ordination and, consequently explain the pattern found are the following: for axis 1 , positively for Bryconamericus sp.1, Hypostomus sp., T. rendalli, Cetopsis sp., C. gomesi and Corydoras sp. 1, and negatively for Hypostomus sp. 1, A. eigenmanniorum, Hy-

Table 1. Abundance (n) of the species captured at the 31 sampling stations located within the Meia Ponte River basin, during the rainy (March/2001) and dry (August/2001) seasons.

\begin{tabular}{|c|c|c|c|c|c|c|c|}
\hline ORDER & & Rainy & Dry & ORDER & & Rainy & Dry \\
\hline Family & Acronym & & & Family & Acronym & & \\
\hline Genus species & & $\mathrm{n}$ & $\mathrm{n}$ & Genus species & & $\mathrm{n}$ & $\mathrm{n}$ \\
\hline CHARACIFORMES & & & & Gymnotidae & & & \\
\hline Anostomidae & & & & Gymnotus carapo & gymcar & 8 & 6 \\
\hline Leporinus microphthalmus & lepmic & 11 & 18 & Sternopygidae & & & \\
\hline Characidae & & & & Eigenmannia trilineata & eigtri & 2 & 3 \\
\hline Astyanax altiparanae & astalt & 20 & 15 & PERCIFORMES & & & \\
\hline Astyanax eigenmanniorum & asteig & 111 & 265 & Cichlidae & & & \\
\hline Astyanax paranae & astpar & 22 & 15 & Cichlasoma paranaense & cicpar & 18 & 7 \\
\hline Astyanax fasciatus & astfas & 129 & 114 & Crenicichla haroldoi & crehar & 0 & 2 \\
\hline Bryconamericus sp.1 & brysp 1 & 231 & 54 & Crenicichla niederleinii & crenie & 1 & 1 \\
\hline Bryconamericus stramineus & brystr & 53 & 216 & Tilapia rendalli & tilren & 4 & 0 \\
\hline Galeocharax sp. & galsp & 1 & 0 & SILURIFORMES & & & \\
\hline Hyphessobrycon sp.1 & hyfsp 1 & 0 & 88 & Callichthyidae & & & \\
\hline Moenkhausia sanctaefilomenae & moesan & 2 & 0 & Aspidoras fuscoguttatus & aspfus & 32 & 0 \\
\hline Odontostilbesp. & odosp & 18 & 13 & Corydoras sp. 1 & corsp 1 & 0 & 6 \\
\hline Oligosarcus planaltinae & olipla & 28 & 14 & Corydoras sp. & corsp & 30 & 129 \\
\hline Piabina argentea & piaarg & 58 & 30 & Cetopsidae & & & \\
\hline Piaractus mesopotamicus & piames & 3 & 0 & Cetopsis $\mathrm{sp}$. & cetsp & 2 & 3 \\
\hline Crenuchidae & & & & Doradidae & & & \\
\hline Characidium cf. gomesi & chacfg & 0 & 4 & Rhinodoras dorbignyi & rhidor & 3 & 0 \\
\hline Characidium gomesi & chagom & 0 & 3 & Heptapteridae & & & \\
\hline Characidium sp. & chasp & 0 & 1 & Cetopsorhamdia iheringi & cetihe & 37 & 42 \\
\hline Characidium zebra & chazeb & 46 & 61 & Imparfinis schubarti & impsch & 11 & 14 \\
\hline Curimatidae & & & & Phenacorhamdia tenebrosa & pheten & 4 & 6 \\
\hline Cyphocharax modestus & cypmod & 0 & 20 & Pimelodella sp. & pimsp & 8 & 17 \\
\hline Cyphocharax sp. & cypsp & 5 & 0 & Rhamdia quelen & rhaque & 12 & 13 \\
\hline $\begin{array}{l}\text { Steindachnerina corumbae } \\
\text { Erythrinidae }\end{array}$ & stecor & 0 & 1 & $\begin{array}{l}\text { Rhamdia sp. } \\
\text { Loricariidae }\end{array}$ & rhasp & 0 & 11 \\
\hline Hoplias malabaricus & hopmal & 5 & 1 & Hypostomus ancistroides & hypanc & 185 & 29 \\
\hline Lebiasinidae & & & & Hypostomus auricular & hypaur & 1 & 0 \\
\hline Pyrrhulina australis & pyraus & 1 & 0 & Hypostomus cf. ancistroides & hypcfa & 0 & 4 \\
\hline Parodontidae & & & & Hypostomus cf. sp. 1 & hypcf1 & 0 & 28 \\
\hline Apareiodon affinis & apaaff & 1 & 0 & Hypostomus cf. sp. 2 & hypcf2 & 0 & 7 \\
\hline Parodon nasus & parnas & 3 & 0 & Hypostomus sp. & hypsp & 149 & 33 \\
\hline Prochilodontidae & & & & Hypostomus sp. 1 & hypsp 1 & 77 & 42 \\
\hline Prochilodus lineatus & prolin & 0 & 1 & Hypostomus sp. 2 & hypsp2 & 69 & 9 \\
\hline CYPRINODONTIFORMES & & & & Hypostomus sp. 3 & hypsp3 & 0 & 3 \\
\hline Poeciliid ae & & & & Hypostomus sp. 4 & hysp 4 & 4 & 0 \\
\hline Poecilia reticulata & poeret & 350 & 446 & Loricaria sp. & lorsp & 7 & 3 \\
\hline GYMNOTIFORMES & & & & Neoplecostomus paranensis & neopar & 20 & 2 \\
\hline Apteronotidae & & & & Trichomycteridae & & & \\
\hline Apteronotus cf. brasiliensis & aptcfb & 2 & 0 & Parastegophilus sp. & parsp & 5 & 3 \\
\hline & & & & Pseudostegophilus sp. & pseusp & 3 & 0 \\
\hline
\end{tabular}


Table 2. Results of the two-way MANOVA/ANOVAs applied on the scores of detrended correspondence analysis (DCA), according to the factors season (rainy and dry) and position (upper, intermediate and lower). Degrees of freedom (D.F.), the statistic associate with MANOVA and ANOVA(R of Rhao and F) and the probability of finding a greater R of Rhao or F than that obtained $(\mathrm{P})$. Values in bold are significant $(\mathrm{p}<$ $0.05)$.

\begin{tabular}{llccc}
\hline \multicolumn{1}{c}{ Tests/variables } & \multicolumn{1}{c}{ Effects } & D.F. & R of Rhao/F & P \\
\hline MANOVA & Season & $3 ; 54$ & 12.16 & $<0.001$ \\
(Axes 1 and 2) & Position & 6,108 & 3.97 & 0.001 \\
& Season*position & $6 ; 108$ & 0.49 & 0.816 \\
& & & & \\
ANOVA & Season & $1 ; 56$ & 19.34 & $<0.001$ \\
(Axis 1) & Position & 2,56 & 5.16 & 0.008 \\
& Season*position & $2 ; 56$ & 0.09 & 0.908 \\
ANOVA & & & & \\
(Axis 2) & Season & $1 ; 56$ & 14.77 & 0.002 \\
& Position & $2 ; 56$ & 6.92 & $<0.001$ \\
& Season*position & $2 ; 56$ & 0.97 & 0.384 \\
\hline
\end{tabular}

phessobrycon sp.1 and Rhamdia sp.; and for axis 2, positively for B. stramineus, Hyphessobrycon sp.1 and $C$. haroldoi, and negatively for Hypostomus sp. 2, A. fuscoguttatus and H. ancistroides.

Thus, the species correlating positively with axis 1 were more abundant in the lower part, whereas the negative ones were more abundant in the upper part, especially in the rainy season (Fig. 4a). For axis 2, the species correlating positively were more abundant in the intermediate (dry season) and lower parts (dry and rainy seasons), while the negative ones were more abundant in the upper part, especially in the dry season (Fig. 4b).

MANOVA applied to species richness, Shannon-Weaver diversity index and equitability did not show significance (factors: season: $\mathrm{P}=0.326$; position: $\mathrm{P}=0.205$; season * position: $\mathrm{P}=0.847)$. These results indicate that the differences found may be obtained at random. We therefore conclude that these variables did not vary between seasons and with regard to position (Table 3).

\section{Discussion}

The fish assemblage of the Meia Ponte River basin differed according to season (rainy and dry) and position (upper, intermediate and lower). The seasonal variations in rain create and/or eliminate micro-habitats and, therefore, are important for fish (Esteves \& Aranha, 1999). Lowe-McConnell (1999) describes rain seasonality as a key factor that affects the strategies of the life cycle of fish, such as movements, feeding, growth and spawning. In addition, Shuter et al. (1980) report that precipitation and temperature promote alterations in species abundance and richness over a large spatial scale, and Grossman et al. (1985) call attention to fact that these factors are also important over a small spatial scale as well, such as for small creeks such as those in this study.

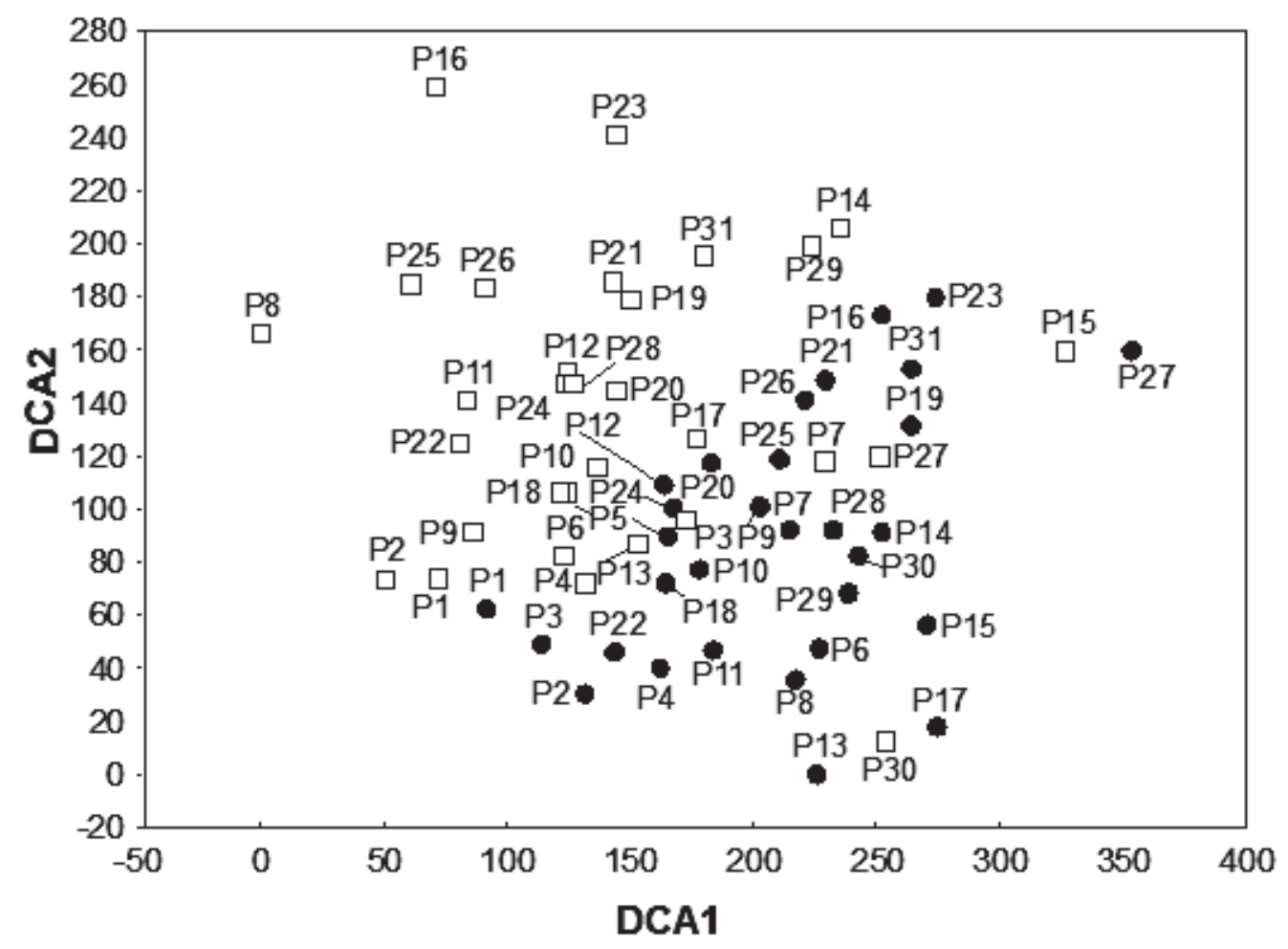

Fig. 3. Ordination of the sampling stations resulting from detrended correspondence analysis (DCA) applied to abundance data matrix. Squares $=$ dry season; black circles $=$ rainy season . 
Table 3. Mean and standard deviation (in parentheses) of indices calculated for sampling stations grouped by season and position in the watershed. $\mathrm{p}=$ ANOVA probability results of comparison between sections.

\begin{tabular}{|c|c|c|c|c|c|c|c|c|}
\hline \multirow[t]{3}{*}{$\overline{\text { Index }}$} & \multicolumn{8}{|c|}{ Sampling station position } \\
\hline & \multicolumn{4}{|c|}{ Rainy } & \multicolumn{4}{|c|}{ Dry } \\
\hline & $\begin{array}{c}\text { Upper } \\
n=9\end{array}$ & $\begin{array}{c}\text { Intermediate } \\
\mathrm{n}=13\end{array}$ & $\begin{array}{c}\text { Lower } \\
n=9\end{array}$ & $\mathrm{p}$ & $\begin{array}{c}\text { Upper } \\
n=9\end{array}$ & $\begin{array}{c}\text { Intermediate } \\
n=13\end{array}$ & $\begin{array}{c}\text { Lower } \\
n=9\end{array}$ & $\mathrm{p}$ \\
\hline Richness & $\begin{array}{l}11.11 \\
(1.09)\end{array}$ & $\begin{array}{c}8.08 \\
(0.91)\end{array}$ & $\begin{array}{c}8.22 \\
(1.09)\end{array}$ & 0.090 & $\begin{array}{c}9.67 \\
(1.28)\end{array}$ & $\begin{array}{c}9.08 \\
(1.07)\end{array}$ & $\begin{array}{c}6.22 \\
(1.28)\end{array}$ & 0.139 \\
\hline Shannon-W eaver & $\begin{array}{c}0.79 \\
(0.05)\end{array}$ & $\begin{array}{c}0.72 \\
(0.04)\end{array}$ & $\begin{array}{c}0.67 \\
(0.05)\end{array}$ & 0.242 & $\begin{array}{c}0.68 \\
(0.06)\end{array}$ & $\begin{array}{c}0.70 \\
(0.05)\end{array}$ & $\begin{array}{c}0.59 \\
(0.06)\end{array}$ & 0.358 \\
\hline Equitability & $\begin{array}{c}0.77 \\
(0.03)\end{array}$ & $\begin{array}{c}0.82 \\
(0.03)\end{array}$ & $\begin{array}{c}0.76 \\
(0.03)\end{array}$ & 0.341 & $\begin{array}{c}0.72 \\
(0.04)\end{array}$ & $\begin{array}{c}0.77 \\
(0.04)\end{array}$ & $\begin{array}{c}0.76 \\
(0.04)\end{array}$ & 0.742 \\
\hline
\end{tabular}

Rains or floods from distant upper parts of a drainage basin lead to increased water velocity and more volume, loads of silt, organic and inorganic materials which will accumulate in the soil for the next dry period. All these alter physical and chemical parameters of the water, such as water velocity, depth, temperature and conductivity, which in turn will influence fish assemblages (Tejerina-Garro et al., 2005). For example, a $20-\mathrm{cm}$ variation in water level at the beginning of the rainy season altered the abundance of Siluriformes in a stream in Panama (Power, 1983). In this study, the rainy season seems to favor bottom-dwelling fish, such as the species of the ge-
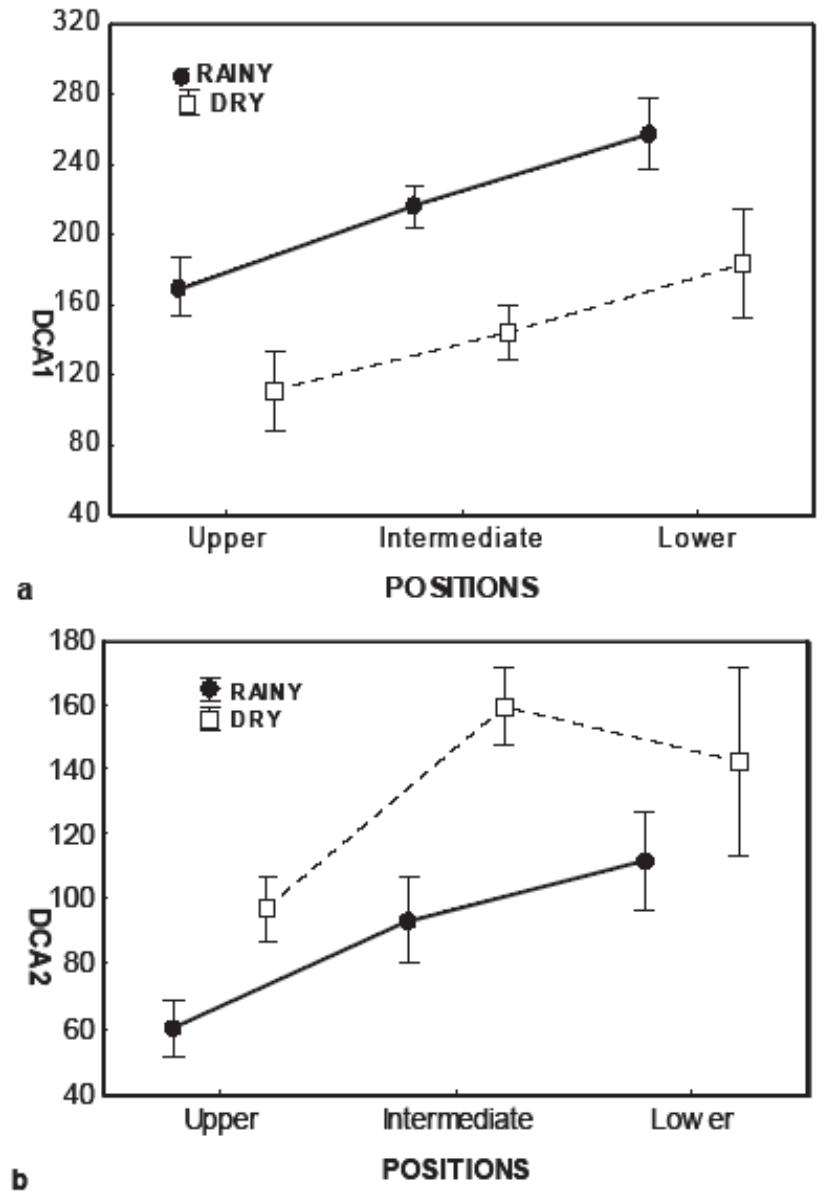

Fig. 4. Mean scores of detrended correspondence analysis (DCA), controlling for seasons (rainy and dry) and positions (upper, intermediate and lower) $(\mathrm{a}=\mathrm{Axis} 1 ; \mathrm{b}=$ Axis 2$)$. nus Hypostomus, Cetopsis, and Corydoras; Froese \& Pauly, 2007) or fish species that prefer running waters such as Characidium gomesi (Fialho \& Tejerina-Garro, 2004).

Therefore, rain seasonality could be considered a key factor that activates and deactivates environmental parameters (Agostinho \& Zalewski, 1995), favoring or even inhibiting man-made impacts, such as deforestation and agriculture, as observed in the Meia Ponte River basin. Although these factors affect fish assemblages including those of streams in the upper Paraná River (Casatti, 2004), they favor species with adaptations that prompt them to thrive in the modified environment (Matthews et al., 1994) such as Astyanax fasciatus, which is considered resistant to water pollution (domestic sewage, pesticides, heavy metals) (Schulz \& Martins-Junior, 2001) and was abundant in collections in the tributaries of the Meia Ponte River basin.

There is a relationship between habitat spatial heterogeneity and habitat selection by fish in streams (Oksanen et al., 1995), as well their spatial and temporal dynamics. Collaborating these affirmations, Schlosser (1982), Moyle \& Senanayake (1984) and Pouilly (1993) found that the longitudinal position is an important variable for fish in streams. This seems to be the case in this study, where fish assemblage varied among positions, mainly between the upper where fish as such Poecilia reticulata, an introduced species, is more abundant, as well as the characins Astyanax fasciatus, and lower section where two characins Bryconamericus sp. 1 and B. stramineus are abundant. However, other authors reported that the longitudinal position along a basin is not always important, noting that morphology and lithology are factors that shape streams, leading to non-organized habitat units (Matthews \& Hill, 1980; Bart, 1989).

On the other hand, Forman \& Godron (1986) stated that in several spatial scales considered, habitats are analyzed as landscapes belonging to a mosaic of interconnected patches, but that they differ substantially concerning the organisms that inhabit them. In this sense, Grenouillet et al. (2004) reported that, for fish assemblages, local species richness is related to the position of the stream along the basin, in addition to local conditions of the habitats. However, in this study species richness did not express differences among sections (position along the watershed), in neither the ShannonWeaver diversity index nor the equitability in both seasons. Apparently, streams of similar order may harbor a limited num- 
ber of species, and they appear to show a similar proportion of abundances. In addition, the lack of differences among these variable indicates the influence of other factors (natural or man-made impacts) on local conditions of the habitat, than on fish assemblages. The non-significance of the interaction season*position on fish assemblage structure seems to reinforce this result. However, it is not discarded the effects of dilution induced by rains on fish sampling, thus in all the results found.

Therefore, the present findings suggest significant differences in the structure of fish assemblages of the Meia Ponte River basin for the seasons (rainy and dry) and positions (upper, intermediate and lower) in spite of the small scale considered. The heterogeneity of the ichthyofauna in the uppermost part of the Paraná River is higher (59 species) than expected in a basin under anthropogenic impacts resulting from multiple uses of water courses, which demonstrates the importance of this area for conservation purposes.

\section{Acknowledgements}

We wish to thank the Agência Ambiental de Goiás, many undergraduate students of the Universidade Católica de Goiás, and the technical staff at the Centro de Biologia Aquática, particularly Waldeir Francisco de Menezes, for their collaboration and support in the field, and two anonymous reviewers for their valuable suggestions. LGO and LCG are supported by CNPQ productivity fellowships.

\section{Literature Cited}

Agostinho, A. A. \& M. Zalewski. 1995. The dependence of fish community structure and dynamics on floodplain and riparian ecotone zone in Paraná River, Brazil. Hydrobiologia, 303: 141-148.

Araújo-Lima, C.A. R. M., L. F. Jiménez, R. S. Oliveira, P. C. Eterovick, U. Mendonza \& A. Jerozolimnki. 1998. Relação entre o número de espécies de peixes, complexidade do hábitat e ordem do riacho nas cabeceiras de um tributário do rio Urubu, Amazônia Central. Acta Limnologica Brasiliensia,11(2): 127-135.

Balon, E. K. 1993. Dynamics of biodiversity and mechanisms of change: a plea for balanced attention to form creation and extinction. Biological Conservation, 66: 5-16.

Bart, H. L. 1989. Fish habitat association in an Ozark stream. Environmental Biology of Fishes, 24: 173-186.

Bistoni, M. A. \& A. C. Hued. 2002. Patterns of fish species richness in rivers of the central region of Argentina. Brazilian Journal of Biology, 62(4B): 753-764.

Casatti, L. 2004. Ichthyofauna of two streams (silted and reference) in the Upper Paraná River basin, Southeastern Brazil. Brazilian Journal of Biology 64: 757-765.

Esteves, K. E. \& J. M. R. Aranha. 1999. Ecologia trófica de peixes de riachos. Pp. 157-182. In: Caramaschi, É. P., R. Mazzoni, P. R. Peres-Neto (Eds.). Ecologia de Peixes de Riachos. Rio de Janeiro, PPGE-UFRJ, Série Oecologia Brasiliensis, vol. 6, 260p.

Feyrer, F. \& M. P. Healey. 2003. Fish community structure and environmental correlates in the highly altered Sacramento-San Joaquin Delta. Environmental Biology of Fishes 66: 123-132.

Fialho, A. P. \& F. L. Tejerina-Garro. 2004. Peixes da bacia do rio Meia Ponte, Goiás. Goiânia, Editora da UCG, 40p.
Forman, R. T. T. \& M. Godron. 1986. Landscape ecology. New York, John Wiley \& Sons, 619p.

Froese, R. \& D. Pauly. 2007. FishBase. World Wide Web electronic publication. www.fishbase.org.version (12/2006).

Gauch Jr., H. G. 1982. Multivariate analysis in community ecology. New York, Cambridge University, 298p.

Gilliam, J. F., D. F. Fraser \& M. Alkins-Koo. 1993. Structure of a tropical stream fish community: a role for biotic interactions. Ecology, 74(6): 1856-1870.

Goiás, 2000. AGÊNCIA AMBIENTAL DE GOIÁS. Relatório rio Meia Ponte 2000. 33p

Gorshkov, V. G., A. M. Makarieva \& V. V. Gorshkov. 2004. Revising the fundamentals of ecological knowledge: the biotaenvironment interaction. Ecological Complexity, 1: 17-36.

Grenouillet, G., D. Pont \& C. Hérissé. 2004. Within-basin fish assemblage structure: the relative influence of habitat versus stream spatial position on local species richness. Canadian Journal of Fisheries and Aquatic Sciences, 61: 93-103.

Grossman, G. D., M. C. Freeman, P. B. Moyle \& J. O. Whittaker.1985. Stochasticity and assemblage organization in an Indiana stream fish assemblage. American Naturalist, 126: 275-285.

Harris, J. H. 1995. The use of fish in ecological assessments. Australian Journal of Ecology, 20: 65-80.

Hughes, R. M. \& J. R. Gammon. 1987. Longitudinal changes in fish assemblages and water quality in the Willamette River, Oregon. Transactions of the American Fisheries Society, 116: 196-209

Jackson, D. A., P. R. Peres-Neto \& J. D. Olden. 2001. What controls who is where in freshwater fish communities- the roles of biotic, abiotic, and spatial factors. Canadian Journal of Fisheries and Aquatic Sciences, 58: 157-200.

Johnson, D. E. 1998. Applied multivariate methods for analysts. California, Duxbury Press, 596p.

Jongman, R. H. G., C. J. F. Ter Braak \& O. F. R. van Tongeren. 1987. Data analysis in community and landscape ecology. Cambridge, Cambridge University Press, 299p.

Lowe-McConnell, R. H. 1999. Estudos ecológicos de comunidades de peixes tropicais. São Paulo, EDUSP, 434p.

Marsh-Matthews, E. \& W. J. Matthews. 2000. Geographic, terrestrial and aquatic factors: which most influence the structure of stream fish assemblages in the Midwestern United States? Ecology of Freshwater Fish, 9: 9-21.

Matthews, W. J. 1998. Patterns in freshwater fish ecology. New York, International Thomson Editors, 752p.

Matthews, W. J., B. C. Harvey \& M. E. Power.1994. Spatial and temporal patterns in the fish assemblages of individual pools in a midwestern stream. Environmental Biology of Fishes, 39: 381-397.

Matthews, W. J. \& L. G. M. Hill. 1980. Habitat partitioning in the fish community of a southwestern river. Southwestern Naturalist, 25: 51-66.

McCune, B. \& M. J. Mefford. 1997. PC-ORD: Multivariate analysis of ecological data. Version 3.0. Oregon, mJm Software Design.

Moyle, P. B. 1995. Conservation of native freshwater fishes in the Mediterranean-type climate of California, USA: a review. Biological Conservation, 72: 271-279

Moyle, P. B. \& F. R. Senanayake. 1984. Resource partitioning among the fishes of rain forest streams in Sri Lanka. Journal of Zoology, 202: 195-223.

Oksanen, T., M. E. Power \& L. Oksanen. 1995. Ideal free habitat selection and consumer-resource. Dynamic Naturalist, 146: 565585 . 
Penczak, T., A. A. Agostinho \& E. K. Okada. 1994. Fish diversity and community structure in two small tributaries of the Paraná River, Paraná State, Brazil. Hydrobiologia, 294: 243-251.

Pouilly, M. 1993. Habitat ecomorphologie et structure des peuplements de poissons dans trois petit cours d'eau tropicaux de Guinée. Revue de Hydrobiologie Tropicale, 26: 313-325.

Power, M. E. 1983. Grazing response of tropical freshwater fishes to different scales of variation in their food. Environmental Biology of fishes, 9: 103-105.

Scheiner, S. M. \& J. Gurevitch. 1993. Design and analysis of ecological experiments. New York, Chapman and Hall, 434p.

Schlosser, I. J. 1982. Fish community structure and function along two habitat gradients in a headwater stream. Ecological Monographs, 52: 395-414.

Schulz, U. H. \& H. Martins-Junior. 2001. Astyanax fasciatus as bioindicator of water pollution of Rio dos Sinos, RS, Brazil. Brazilian Journal of Biology, 61: 615-622.

Shuter, B. J., J. A. Maclean, F. E. J. Fry \& H. A. Regier. 1980. Stochastic simulation of temperature effects on first-year survival of smallmouth bass. Transaction of the American Fisheries Society, 109: 1-34.
Solé, R.V., A. C. D. Alonso \& D. J. Saldaña. 2003. Habitat fragmentation and biodiversity collapse in neutral communities. Ecological Complexity, 1: 65-75.

Tejerina-Garro, F. L., M. Maldonado, C. Ibañez, D. Pont, N. Roset \& T. Oberdorff . 2005. Effects of natural and anthropogenic environmental changes on riverine fish assemblages: a framework for ecological assessment of rivers. Brazilian Archives of Biology and Technology, 48(1): 91-108.

Uieda, V. S. \& M. G. Barretto. 1999. Composição da ictiofauna em quatro trechos de diferentes ordens do rio Capivara, bacia do Tietê, Botucatu, São Paulo. Revista Brasileira de Zoociências, 1(1): 55-67

Wiens, J. A. 2002. Riverine landscapes: taking landscape ecology into the water. Freshwater Biology, 47: 501-515.

Williams L. R., C. M. Taylor, M. L. Warren Jr. \& J. A. Clingenpeel. 2003. Environmental variability, historical contingency, and the structure of regional fish and macroinvertebrate faunas in Ouachita, mountain stream systems. Environmental Biology of Fishes, 67(2): 203-216.

Received October 2006

Accepted March 2007 